\title{
Göçmen Öğrencilerin Eğitim Süreci Açısından Okullar Arası İşbirliğine İliş̧kin Okul Yöneticilerinin Görüşleri *
}

Esen Altunay $^{* * 1}$ ve Mehmet Dede ${ }^{2}$

Öz

Anahtar Sözcükler

$\mathrm{Bu}$ araştırmanın temel amacı göçmen öğrencilerin eğitim süreci açısından okullar arası işbirliğine ilişkin okul yöneticilerinin görüşlerinin tespit etmek ve bu konuda uygulayıcılara öneriler sunmaktır. Araştırma nitel araştırma yöntemlerinden fenomenolojik desen ile desenlenmiştir. Araştırmanın çalışma grubu 2017-2018 eğitim öğretim yılında görevli 28 okul yöneticisinden oluşmaktadır. Araştırmada amaçlı örnekleme yöntemlerinden kritik durum örneklemesi kullanılmıştır. Kritik durum olarak dezavantajlı ve yoğun göç alan bölgelerdeki okulların durumu alınmıştır. Araştırmada veri toplama aracı olarak araştırmacılar tarafından geliştirilmiş yarı yapılandırılmış görüşme formu kullanılmıştır. Araştırmanın bulgularına göre: göçe bağlı olarak karşılaşılan sorun alanlarından dil bilmemeye bağlı sorun alanları, ekonomik yetersizlikler ve öğrencilerin duygusal sorun yaşamaları, eğitim alanında karşılaşılan sorunların nedeni olarak dil bilmeme, ekonomik yetersizlikler ve artan öğrenci sayıları bulgularına ulaşılmıștır. Ayrıca okul yöneticilerinin karşılaştıkları sorunları okullarında açılan dil kurslarıyla çözmeye çalıştıkları, farklı okullarda üretilen çalışmalar hakkında fazla bilgilerinin olmadığı, farklı okul yöneticileri ile düzensiz aralıklarla iletişim kurdukları ve okullar arası işbirliği geliştirme konusunda

Okullar arası işbirliği Sosyal sermaye Göçmen eğitimi

Makale Hakkında

Gönderim Tarihi

23 Ekim 2018

Kabul Tarihi

14 Ocak 2019

Makale Türü

Araştırma Makalesi

DOI: $10.12984 /$ egeefd. 474018

\section{School Administrators' Opinions about Cooperation among Schools in the Training Process of Immigrant Students"}

\section{Abstract}

Keywords

The main objective of this research is to determine school administrators' opinions about cooperation among schools in the training process of immigrant students and providing suggestions to the implementers in this respect. The research was designed with the phenomenological design of qualitative research methods. The study group consisted 28 school administrators who were in charge during the academic year 2017-2018. As a purposeful sampling method, critical case sampling was used in the research. As a critical case, the situation of schools in disadvantaged and high immigrant-receiving regions has been studied. A semi-structured interview form developed by the researcher was used as data collection tool. The findings revealed that the problem areas were related to language problems, economical inadequacies and emotional problems of students, lack of language as an underlying cause of problems in education, economic insufficiency and increasing number of students. The findings also showed that school administrators tried to solve the problems they encountered through language courses opened; they had insufficient information regarding the efforts carried out in other schools; they had communicated at irregular intervals and they needed to exchange information by conducting meetings to develop cooperation.

Atıf: Altunay, E. ve Dede, M. (2019). Göçmen öğrencilerin eğitim süreci açısından okullar arası işbirliğine ilişkin okul yöneticilerinin görüşleri. Ege Eğitim Dergisi, 20(1), 127-144. doi:10.12984/egeefd.474018

\footnotetext{
* Bu çalışma, 10-12 Mayıs 2018 tarihleri arasında Sivas’ta düzenlenen 13. Uluslararası Eğitim Yönetimi Kongresinde sunulmuştur. [This study was partly presented at the $13^{\text {th }}$ International Congress on Educational Administration in Sivas, May 10-12, 2018]

${ }_{* *}$ Sorumlu Yazar/Corresponding Author

1 (D) Ege Üniversitesi, Eğitim Fakültesi, Eğitim Bilimleri Bölümü, Türkiye, esenaltunay@yahoo.com

2 Cemil Atlas Ortaokulu, Bayraklı, İzmir, Türkiye, mehmet2de@gmail.com
} 


\section{Extended Abstract}

\section{Introduction}

In the educational process of immigrant students, continuous and healthy communication among the school as an organization and its neighborhood is vital for reaching results, because establishing the school-neighborhood relationship provides the school with the ability to recognize the neighborhood with its basic features and to introduce itself to the neighborhood. Collaboration with the neighborhood and other schools can provide a fast and effective solution to dealing with school problems. Collaboration with the neighborhood and other schools can make it easier to reach common goals, provide a fast and effective solution to problems, and particularly it accelerates immigrant students' adaptation to the society. Meanwhile, it can also have a positive impact on individuals and society both in social and economical terms. Thus, thanks to schools that lead to change and overcome the pain of change, healthy individuals can be introduced into society. In this context, whether it is seen as an obligation or an opportunity, the notion of inter-school cooperation, which has an important role for the development of society and expresses the harmony of the school and its neighborhood, plays an important role in the education of children. In some of the studies in the literature on the training process of immigrant students and the problems encountered during this process, it is seen that Turkey's education policies and recommendations towards, especially, Syrian refugees are evaluated. In addition, in some of the studies, problems and academic achievements of immigrant students in relation with migration are examined. However, we have so far not encountered any study examining the issue of inter-school cooperation during the education process of immigrant students and for the solution of the problems. In this regard, this study aims to be a valuable contribution to the existing literature. From this point of view, the main purpose of the study is to examine school administrators' opinions about the development of inter-school cooperation in terms of the educational process of immigrant students and to present suggestions. The sub-problems identified to achieve the aimed results are:

1. What are the opinions of the school administrators on migration related to the problem areas they face?

2. What are the opinions of the school administrators on reasons of the problems that immigrant students face during their education process?

3. What are the opinions of the school administrators on solutions of the problems that immigrant students face during their education process?

4. What are the opinions of school administrators on solutions produced in other schools for problems related to immigrant students?

5. What are the opinions of school administrators on the development of cooperation between schools for the solution of the problems faced by immigrant students during the education process?

\section{Method}

In this study, among the types of qualitative research designs, the phenomenological (phenomenon) design was used as a realistic, natural and holistic approach was followed to reveal the views of school administrators about the inter-school cooperation in terms of the education process of immigrant students in primary schools. The study group of this research consisted school administrators in Bayraklı, Bornova and Karabağlar districts of İzmir in the 2017-2018 academic year. The group composed of 18 school principals and 10 vice-principals. In this study, among the purposeful sampling methods, critical situation sampling was used. As the critical situation, the condition of schools in the disadvantaged regions, which received intensive migration, was taken into account. Semi-structured interview technique was used in the research. In the study, interviews were audio recorded with the permission of the administrators, and the audio recordings were transcribed to the computer for the analysis. In this way, it is aimed to make analyzes complete and accurate as well as not to miss any details. Descriptive and content analysis was used for the analyses of the data.

\section{Findings}

It is seen that there are themes developed in line with the five sub-problems of the study. Fifteen themes emerged after the analysis of the data on the opinions of the school administrators regarding the inter-school cooperation in terms of the educational process of immigrant students. As a result of the analysis of the data regarding migration-related problem areas, four codes emerged as family-related problem areas, student-related problem areas, structural-based and teacher-related problem areas. As a result of the analysis of the data regarding the solutions produced in the process of migrant education, three codes emerged as interaction, education and 
developing cooperation. As a result of the analysis of data on the school administrators' awareness on solutions produced in other schools, two codes emerged as those who are partially aware of the solutions and those who are not aware of the solutions. As a result of the analysis of the opinions of the school administrators on the use of the solutions produced in other schools and the cooperation between schools, five codes emerged as Application-oriented cooperation, education-oriented cooperation, staff-oriented cooperation, information sharing-based cooperation, and organizational-focused cooperation.

\section{Discussion and Conclusion}

This research examined the problems encountered by school administrators in the process of education of immigrant students and suggestions for cooperation to solve these problems. As the school administrators underline communication problems due to the language barrier, economic insufficiency and emotional trauma among students as the main problem areas, the schools and social services directorates may cooperate to provide financial support for students who are in need and may organize activities for integration and social cohesion with families in schools. As the school administrators underline language barriers, economic insufficiency and increasing number of students as the most common cause for the problems faced by the immigrant students during the education process, the Ministry of National Education should make plans for the reduction of class sizes and prevent the accumulation of students to certain schools. As the school administrators get information about the solutions produced in other schools for the problems of migrant students through the irregular interactions, it may be useful to create an information pool of solutions that produced by teachers and school administrators who are working in migrant-receiving regions for the use of other schools. 


\section{Giriş}

Eğitim kurumları olarak okullar, sürekli yeniliğe açık, bilginin üretildiği, kullanıldığı ve geliştirildiği, ekip çalışması ile insanın kendine güven sağladığı, günün her saatinde kullanıma açık, toplumun yeni bilgi ihtiyaçlarının karşılandığı, öğrencide özgün ve yaratıcı düşünceyi geliştirmeyi amaçlayan, çok fonksiyonlu bir yapıda olmak zorundadır (Parlar, 2012). Okullar bu nitelikleri ile toplumun bir denge içinde yaşamasını, sorunlarla baş etmesini, yeniliğe uyumunu sağlar, ancak okul işlevini gerçekleştiremezse toplumsal çatışmalar ortaya çıkabilir. Örneğin göçler toplumun dengesinin sarsılmasına neden olan önemli değişkenlerden biridir. Göçler herhangi bir nedenle yerleşik kültürden ayrılma, yeni bir dil, yeni bir kültür, yeni bir ortamla karşılaşma içerdiği için yeni sorunlar oluşmasına neden olmakta ve bireylerde uyum problemleri yaratmaktadır (Kılınç, 2014:Akt. Çatalbaş, Sarıtaş ve Şahin, 2016). Öte yandan bireyler okullarda verilen eğitim yolu ile gerekli desteği aldıklarında savaş ve göçün etkisinden büyük oranda kurtulabilmekte, bunun yanında gelecekte sahip olacakları işler için gerekli olan beceri ve vasıfları elde etme şansına sahip olabilmektedirler. Çocukların eğitim imkânı ellerinden alındığı zaman, geleceğe ilişkin umutları yok olmakta, yoksulluk nesiller arasında aktarılmakta ve yeniden üretilmekte, bunun sonucunda da sosyal istikrarsızlık kalıcı hale gelip toplumun yeniden oluşum beklentisi yok olmaktadır (Eğitim Bir Sen, 2017). Nitekim 2011 yılı itibariyle başlayan Suriye iç savaş1 neticesinde açık kapı politikası uygulayan Türkiye, tarihin en büyük göç hareketiyle yüzleşmek zorunda kalmıştrr. Türkiye'de bulunan ve öğrenim gören göçmen öğrencilere ilişkin veriler incelendiğinde; eğitim çağındaki çocuk sayısının 746.000 olduğu ve bu çocuklardan 451.000'nin okula gitmediği UNICEF raporunda görülmektedir. Bununla birlikte 2016-2017 eğitim-öğretim yılında 23.971 Irak vatandaşının, 12.782 Afganistan vatandaşının Türkiye'de eğitim gördüğü bilinmektedir (Göç İdaresi Genel Müdürlüğü, 2017). Hal böyle olunca eğitim sistemi de göçe bağlı olarak daha da artan genç nüfusun eğitimi ve topluma kazandırılması konusunda ciddi bir sorunla yüzleşmek zorunda kalmaktadır. Eğitim sisteminin karşı karşıya kaldığı bu durum dikkate alınmadığında okullaşamayan genç göçmenlerin olanakları ellerinden alınmış olmakta ve böylece gençler yeni firsatlar elde etmek için zorlu/ ölümcül yolculuklar yapma, radikal gruplara katılma gibi seçeneklere yönelebilmektedirler (Watkins ve Zycks, 2014: akt. Eğitim Bir Sen, 2017).

Göçler neticesinde gerek eğitim yapısı gerek toplumsal yapıda olumsuz değişimler yaşanmaktadır. UNICEF'in raporuna göre Türkiye'de bugüne dek elde edilen kazanımlara ve ciddi çabalara rağmen okula gitmeyen 450 binden fazla okul çağındaki göçmen çocuğun eğitim ihtiyaçlarının giderilmesi için daha ileri seviyede çalışmalar gerekmektedir. Çünkü göçmen çocukların, bir savaşı ve onun acılarını yaşamaları nedeniyle; şiddet, psikolojik bozukluklar, çocuk evlilikleri ve silahlı gruplara dâhil edilme gibi risklerle karşı karşıya kalmaktadırlar. Dolayısıyla uyguladığı açı kapı politikası nedeniyle Türkiye'de göçmen çocukların korunma ve eğitim gereksinmeleri haliyle büyümekte ve gün geçtikçe daha da artmaktadır. Göçmen çocukların eğitimi için çeşitli eğitim politikaları gecikmeli de olsa geliştirilmiş ve uygulamalar hayata geçirilmiştir. Türkiye bu sorumluluğun gereklerini yerine getirmek için uluslararası kuruluşlarla da işbirliği yapmaktadır (UNICEF, 2015). Türkiye'nin üyesi olduğu Birleşmiş Milletler Çocuk Hakları Sözleşmesi'nin 22. Maddesi ve bu uluslararası sözleşmeye ek olarak, 5395 sayılı Çocuk Koruma Kanunu dikkate alındığında ülke sınırları dahilin de ki her çocuğun kanun ve sözleşmede belirtilen şekliyle korumadan yararlanabileceği belirtilmektedir. Bu yasal dayanaklara göre göçmen çocukların da dahil olduğu tüm çocukların temel haklarını koruyan önlemlerin alınması gerekmektedir. Dolayısıyla okullaşmanın ve eğitimin özellikle göçmen çocuklar için ne derece önemli olduğu bir kere daha kendini göstermektedir.

Göçmen öğrencilerin eğitimi sürecinde bir örgüt olarak okul ile çevresi arasında sürekli ve sağlıklı iletişim, sonuç alabilmek için hayati bir öneme sahiptir. Çünkü okul-çevre ilişkisinin kurulması okulun hizmet sunduğu çevreyi temel özellikleriyle tanıma ve kendisini çevresine tanıtma işlevlerinin gerçekleştirilmesini sağlamaktadır. Okul-çevre ilişkisinin sağlanması ile okulun amacını gerçekleştirici bir yapı kurulur ve işleyiş sağlanır (Aydın, 2002). Dolayısıyla okul örgütü çevresinden bağımsız düşünülmeyecek açık bir sistemdir. Yaşama ve gelişmesi çevresine uyum sağlayabilme kapasitesine bağlıdır(Aydoğan, 2013). Öte yandan toplum hayatında meydana gelen sosyal, ekonomik ve politik değişimlerle birlikte okul kurumu ve kurumun çevresinde yenileşmeler ve değişimler yaşanmaktadır. Bu nedenle okullar çevresiyle etkileşim içinde iken çevreden sağladığı geri bildirimle ve entropiyi yenerek yaşamını sürdürmeye çalışmaktadır (Aydoğan, 2013; Katz ve Kahn, 1977). Bu açıdan bakıldığında modern yönetim kuramları ve yeni kurumsalcılık kuramının vurguladığı şekilde biçimsel örgüt yapıları ile bu yapıların gelişimine katkı sağlayan sosyal süreçler arasındaki ilişkilere yönelik olarak (Dillard, Rigsby ve Goodman, 2004:Akt. Bolat ve Seymen, 2006) örgütler, kurumsal çevrelerindeki olgular tarafindan kurgulanmakta ve onlara benzeme eğilimi göstererek varlığını sürdürmektedirler. Böylece biçimsel örgütler zamanla teknik ve dönüşümsel karşılıklı bağımlılıklar yoluyla kurumsal çevrelerine uyumlu hale gelmektedirler(Bolat ve Seymen, 2006; Meyer ve Rowan, 1977; Selznick, 1996).Bu anlamda okullarda çevrenin yeteneğinin değerlendirilmesi, süreklilik gösteren bir yönetimsel sorumluluktur. Yönetici, bu konuda sosyal, ekonomik, kültürel ve siyasal etkenlerin çözümlemesi için nesnel prosedürler geliştirebilir (Göksoy, 2013). Bu çerçeveden bakıldığında toplum, göç olgusu ile değişirken dış baskı ile okullar değişime zorlanmakta ve okul 
yönetimleri çözüm yolları bulurken okulun içyapısı yeniden şekillenmektedir. Okulların bu sorunlarla baş etmelerinde çevreleri ve diğer okullarla kurulan işbirlikleri, sorunların hızlı ve etkili çözümünü sağlayabilmektedir.

Okullar arası işbirliğinin kavramsal temellerinin açıklanmasında bölgesel temelde örgütlenme ya da işlevlerine bakılmaksızın bir coğrafi alanda çalışanların bir araya getirilerek bir arada çalışmalarını öneren Gulick'e (1937) kadar gidilebilir. Goes ve Park (1997) ve Kraatz'a (1998) göre sosyal bir sistem olarak okul, çevresinden etkilenirken bir taraftan da çevresini değiştirmektedir. Okullar çevresini kontrol etmek için çevresindeki örgütlerle bağlantılar kurduğunda örgütsel güveni artabilir, belirsizliği azaltabilir, kritik kaynakların temini ile performansını artırabilir. Üstelik diğer örgütlerle olan güçlü bağlar, artan iletişim yoluyla uyum ve yeniliği, enformasyonu paylaşmayı ve esnek stratejileri öğrenmeyi geliştirmektedir. Okullar çevresi ile yenilik ve araştırma projeleri yoluyla ortaklıklar şekillendirerek risk ve maliyetleri paylaşabilirler. Okul örgütleri arasındaki işbirliği girişimlerine çok amaçlı okul projeleri, vakıf okulları ile uygulama, geliştirme, okul-iş deneyimi programları gibi projelerin yaratılması ve uygulanması örnek olabilir. Okullar arası işbirliği bağlantılar kurulmasını, bağlantılar kurulması sosyal sermayenin etkin kullanılmasını gerektirir. Sosyal sermaye kavramının tarihsel kökenleri 1900'lerin başına dayanmaktadır. L.J.Hanifan'ın 1916 yılında Batı Virginia'daki kırsal okul aile birliği merkezlerini değerlendirmesi kavramsal olarak sosyal sermayenin başlangıcı olarak kabul edilmektedir. Sosyal sermaye kavramı, karşılıklı ilişkilerden meydana gelen ilişki ağlarına sahip olma ve üyelerinin desteğini sağlayan kaynakların toplamı (Bourdieu 2010: Akt. Keleş, 2012) olarak tanımlanmaktadır. Bu nedenle sosyal sermaye kuramına göre insan ilişkileri önemlidir ve zamanla geliştirilen ilişkiler aracılığıyla insanlar kendi başlarına üstesinden gelemeyecekleri ya da güçlükle başarabileceklerini gerçekleştirmek için beraber çalışabilmektedirler (Field, 2006: Akt. Keleş, 2012). Sonuç olarak okul örgütü elindeki sosyal sermayesini etkili kullandığında okullar arası işbirliğini tesis etmesi mümkündür. $\mathrm{Bu}$ aşamada okullar karşılaş̧ıkları sorunları işbirliği ağları ile kendi başlarına çözemeyecekleri ya da zorlukla çözebilecekleri sorunları beraber çözebilmektedirler. Dolayısıyla okulların çevresi ve diğer okullarla olan işbirliği ortak amaçlara ulaşmayı kolaylaştırabilmekte, sorunların hızlı ve etkili çözümünü sağlayacak ve özellikle göçmen öğrencilerin topluma uyum sağlamaları, birey ve toplum için hem sosyal hem de ekonomik anlamda olumlu etkileri olabilmektedir. Böylece değişime yön veren ve değişimin sancılarını atlatmış okullar, sayesinde sağlıklı bireyler topluma kazandırılmış olabilmektedir.

Okullarda kurumsallaşma iyi şekilde geliştiğinde farklı bakış açıları, alışkanlıklar ve diğer bütünleşmeler, üyelerin sosyal bütünleşmesini getirmektedir (Selznick, 1957). Ancak okullar gereksinimleri olan kaynakları üretemedikleri için çevresel bağlamda bir değişime girerek kaynakları temin etmeye çalışmaktadır (Pfeffer, 1997). Zamanla çevrelerine artan bir bağımlılık içerisinde bir sorunun başka bir sorun ile veya katılım programları gibi örgütler arası ilişkileri aktive ederek yol almak zorunda kalmaktadırlar (Aiken ve Hage, 1968; Aldrich ve Mindlin, 1978). Bu bağlamda ister bir zorunluluk ister bir olanak olarak görülsün çocukların eğitiminde ve toplumun gelişiminde büyük rolü olan okul ve çevresinin birbirine uyumunu ifade eden okullar arası işbirliği kavramı, özellikle göçmen çocukların eğitiminde büyük önem taşımaktadır. Alanyazında göçmen öğrencilerin eğitimi süreci ve bu süreçte karşlaşılan sorunların incelendiği bazı çalı̧̧malarda özellikle Suriye'den Türkiye'ye yönelik göç karşısında Türkiye'nin eğitim politikalarının incelendiği (Emin, 2016; Ereş, 2017; İnce, 2016; Sakız, 2016; Seydi, 2014) ve buna yönelik önerilerin geliştirildiği çalışmalar görülmektedir. Ayrıca yapılan bazı araştırmalarda göç ve göçe bağlı olarak eğitim süresince göçmen öğrencilerin yaşadığı sorunlar ve akademik başarılarının incelendiği (Bütün ve Uzun, 2016; Hacıfazlıoğlu, Karaırmak ve Öztabak, 2015; Kılıç ve Yıldız, 2013; Şen, 2016) araştırmalar görülmektedir. Ancak alanyazında göçmen öğrencilerin eğitim süreci ve bu süreçte sorunların çözümü için okullar arası işbirliği konusunu inceleyen herhangi bir çalışmaya erişilememiştir. Bu bağlamda bu çalışmanın alanyazına bir katkı sağlayabileceği umulmaktadır.

$\mathrm{Bu}$ araştırmanın amacı, göçmen öğrencilerin eğitim süreci açısından okullar arası işbirliğinin geliştirilmesine ilişkin okul yöneticilerinin görüşlerini incelemek ve öneriler sunmaktır. Bu amaca ulaşmak için yanıt aranan sorular şöyledir:

1. Okul yöneticilerinin göçe bağlı olarak karşılaştıkları sorun alanlarına ilişkin görüşleri nelerdir?

2. Okul yöneticilerinin göçmen öğrencilerin eğitim sürecinde karşlaştı̆ı sorunların nedenlerine ilişkin görüşleri nelerdir?

3. Okul yöneticilerinin göçmen öğrencilerin eğitim sürecindeki sorunlara ilişkin uyguladıkları çözüm yollarına ilişkin görüşleri nelerdir?

4. Okul yöneticilerinin göçmen öğrencilerle ilgili sorunlara yönelik başka okullarda üretilen çözümlerle ilgili görüşleri nelerdir?

5. Okul yöneticilerinin göçmen öğrencilerin eğitim sürecinde karşılaştıkları sorunların çözümünde okullar arasında iş birliğinin geliştirilmesine ilişkin görüşleri nelerdir? 
Yöntem

\section{Araştırmanın Deseni}

Bu çalışmada ilköğretim okullarda göçmen öğrencilerin eğitim süreci açısından okullar arası işbirliğine ilişkin okul yöneticilerinin görüşlerinin gerçekçi, doğal ve bütüncül bir şekilde ortaya konmasına yönelik nitel bir süreç izlendiği için nitel araştırma desenlerinden fenomenolojik (olgubilim) desen kullanılmıştır.

\section{Çalışma Grubu}

Araştırmanın çalışma grubunu 2017-2018 eğitim öğretim yılında İzmir'in Bayraklı, Bornova ve Karabağlar ilçelerindeki yöneticiler oluşturmaktadır. Çalışma grubu 18 okul müdürü ve 10 müdür yardımcısından oluşturmaktadır. Araştırmada amaçlı örnekleme yöntemlerinden kritik durum örneklemesi kullanılmıştır. Kritik durum olarak yoğun göç alan ve dezavantajlı bölgelerdeki okulların durumu alınmıştır. Gizlilik ilkesi gereği araştırmaya katılan okul müdür ve müdür yardımcılarının gerçek isimlerinin kullanılması yerine kodlar kullanılarak sembolize edilmiştir. Örneğin; 1. Okul müdürü için M1, müdür yardımcısı için MY1 kodu kullanılmıştır. Araştırmaya katılan katılımcıların bireysel özelliklerine göre dağılımı Tablo 1'de sunulmaktadır.

Tablo 1

Çalışma Grubunun Bireysel Özelliklere Göre Dağılımı

\begin{tabular}{llll}
\hline Değişkenler & & $N$ & $\%$ \\
\hline Yaş & $25-30$ yaş & 1 & 3.57 \\
& $31-40$ yaş & 10 & 35.71 \\
& $41-50$ yaş & 10 & 35.71 \\
Cinsiyet & 51 ve üzeri & 7 & 25 \\
& Erkek & 21 & 75 \\
Eğitim Durumu & Kadın & 7 & 25 \\
& Lisans & 23 & 82.14 \\
Yöneticilikteki Kıdem & Yüksek Lisans & 4 & 14.28 \\
& Doktora & 1 & 3.57 \\
Kurumdaki Çalışma Süresi & $1-10$ yıl & 16 & 57.14 \\
\multirow{2}{*}{ Toplam } & $11-20$ yıl & 11 & 39.28 \\
& 20 ve üzeri & 1 & 3.57 \\
& $1-4$ Yı̀l & 23 & 82.14 \\
& 5 yıl ve üzeri & 5 & 17.85 \\
\end{tabular}

Tablo 1 incelendiğinde katılımcıların çoğunun 31-50 yaş aralığında ( $n=20, \%$ 71.42) oldukları, cinsiyet olarak katılımcıların çoğunun erkek $(n=21, \% 75)$, eğitim durumu olarak büyük çoğunluğunun lisans $(n=23, \% 82.14)$ düzeyinde eğitim aldıkları görülmektedir. Ayrıca yöneticilerin 1-10 yıllık yöneticilik kıdemlerinin $(n=16, \%$ 57.14) olduğu ve okullarında 1-4 yıldır ( $n=23, \%$ 82.14) yöneticilik yaptıkları dikkat çekmektedir.

\section{Veri Toplama Aracı}

Araştırmada yarı-yapılandırılmış görüşme tekniği kullanılmıştır. Yarı yapılandırılmış görüşme formu için görüşme soruları araştırmacılar tarafından önceden hazırlanmış; görüşme sırasında araştırılan kişilere kısmi esneklik sağlayarak oluşturulan soruların tekrardan düzenlenmesine, artırılmasına ya da eksiltilmesine izin verilmiştir.

Araştırmanın verilerinin toplanması için görüşme formu hazırlanırken öncelikle alanyazın dikkate alınmıştır. İkinci olarak taslak form Eğitim Yönetimi alanında çalışan iki öğretim üyesine uzman görüşüne sunularak görüşme formunun güvenirlik ve geçerliliği sağlanmaya çalışılmıştır. Görüşme formuna son şekli uzman incelemesinin sonunda, araştırmacılar tarafından, daha ayrıntılı ve odaklı bilgi elde edebilmek amacıyla, sonda soruları eklenerek verilmiştir. Soruların anlaşılır, net ve açık olup olmadığı iki pilot görüşme sonunda yapılan düzenleme ile kontrol edilmiştir.

\section{Veri Analizi}

Araştırmada eğitim yöneticileriyle yapılan görüşmeler yöneticilerin izinleri alınarak ses kaydına alınmış, alınan bu ses kayıtlarının analizlerinin yapılabilmesi için araştırmacılar tarafından ses kayıtları bilgisayara aktarılmış ve bu işlemden sonra analizler yapılmıştır. Ses kayıtları öncelikle yazıya aktarılmıştır. Bu yolla analizlerin tam ve doğru yapılabilmesi amaçlanmıştır. Bu sayede gözden kaçabilmesi olası detayların önüne geçilmeye çalışılmıştır. Araştırmada verilerin analizinde betimsel ve içerik analizi kullanılmıştır. Betimsel analiz için analiz öncesi 
araştırma soruları ve alanyazın doğrultusunda tema listesi belirlenerek analize başlarken bu temalar dikkate alınarak veriler gruplara atanmıştır. İçerik analizinde toplanan verileri açıklayabilecek kavram ve ilişkilere ulaşmak amaçlanmıştır. Araştırmanın temalarının oluşturulmasında birbirine benzeyen verilerin belirli kavramlar çerçevesinde birleştirilerek anlaşılır biçimde kategorize edilip yorumlanması sonucu anahtar kelime ya da söz öbekleri oluşturulmuştur.

Yapılan görüşmeler 1'den başlanılarak numaralandırılmıştır. Brott ve Myers'ın (2002) önerdiği şekilde okul yöneticilerinin aktardığg düşünceler görüşme soruları ve araştırmanın hedefi çerçevesinde kodlanmıştır. Analizler iki araştırmacı tarafından ayrı ayrı yapılmış ve karşılaştırılmıştır. Ayrıca yapılan analiz Eğitim Yönetimi uzmanı olan bir öğretim üyesi tarafından tekrar edilerek alınan geri bildirimlerle birlikte tema ve alt temalara son hali verilmiştir. Bunda amaç araştırma verilerinin güvenilirliğinin artırılmasıdır. İçerik analizi sonucunda elde edilen temalar Tablo 2'de verilmektedir.

Tablo 2

Verilerin Analizi Sonucu Ortaya Çıkan Temalar

\begin{tabular}{|c|c|}
\hline Araştırma Soruları & Temalar \\
\hline $\begin{array}{l}\text { Okul yöneticilerinin göçe bağlı olarak karşılaştıkları sorun } \\
\text { alanlarına ilişkin görüşleri }\end{array}$ & $\begin{array}{l}\text { Aileye bağlı sorun alanları } \\
\text { Öğrenciye bağlı sorun alanları } \\
\text { Yapısal temelli sorun alanları } \\
\text { Öğretmene bağlı sorun alanları }\end{array}$ \\
\hline $\begin{array}{l}\text { Okul yöneticilerinin göçmen öğrencilerin eğitim sürecinde } \\
\text { karşılaştığı sorunların nedenlerine ilişkin görüşleri }\end{array}$ & $\begin{array}{l}\text { Aileye bağlı nedenler } \\
\text { Öğrenciye bağlı nedenler } \\
\text { Yapısal temelli nedenler }\end{array}$ \\
\hline $\begin{array}{l}\text { Okul yöneticilerinin göçmen öğrencilerin eğitim sürecindeki } \\
\text { sorunlara ilişkin uyguladıkları çözüm yollarına ilişkin görüşleri }\end{array}$ & $\begin{array}{l}\text { Etkileşim geliştirme } \\
\text { Eğitim } \\
\text { İşbirliği geliştirme }\end{array}$ \\
\hline $\begin{array}{l}\text { Okul yöneticilerinin göçmen öğrencilerle ilgili sorunlara yönelik } \\
\text { başka okullarda üretilen çözümlerle ilgili görüşleri }\end{array}$ & $\begin{array}{l}\text { Çözümlerin farkında olmayanlar } \\
\text { Çözümlerin kısmen farkında olanlar }\end{array}$ \\
\hline $\begin{array}{l}\text { Okul yöneticilerinin göçmen öğrencilerin eğitim sürecinde } \\
\text { karşılaştıkları sorunların çözümünde okullar arasında iş birliğinin } \\
\text { geliştirilmesine ilişkin görüşleri }\end{array}$ & $\begin{array}{l}\text { Uygulama odaklı işbirliği } \\
\text { Eğitim öğretim odaklı işbirliği } \\
\text { Personel odaklı işbirliği } \\
\text { Bilgi paylaşımı odaklı işbirliği } \\
\text { Örgütsel odaklı işbirliği }\end{array}$ \\
\hline
\end{tabular}

Tablo 2 incelendiğinde araştırmanın beş araştırma sorusu doğrultusunda geliştirilen temaların olduğu görülmektedir. Göçmen öğrencilerin eğitim süreci açısından okullar arası işbirliğine ilişkin okul yöneticilerinin görüşlerine ait verilerin analizi sonucunda 15 tema ortaya çıkmıştır. Göçe bağlı olarak ortaya çıkan sorun alanlarına ilişkin verilerin analizi sonucunda aileye bağlı sorun alanları, öğrenciye bağlı sorun alanları, yapısal temelli ve ögretmene bă̆lı sorun alanları olarak dört tema ortaya çıkmıştır. Göçmen öğrencilerin eğitimi sürecinde karşılaşılan sorunların nedenlerine ilişkin verilerin analizi sonucunda aileye bağlı nedenler, yapısal temelli nedenler ve ögrenciye bağlı nedenler olarak üç tema ortaya çıkmıştır. Göçmen eğitimi sürecinde ortaya çıkan sorunlara yönelik üretilen çözümlere ilişkin verilerin analizi sonucunda etkileşim, eğitim ve işbirliği geliştirme olarak üç tema ortaya çıkmıştır. Okul yöneticilerinin sorunların çözümüne ilişkin başka okullarda üretilen çözümlere ilişkin verilerin analizi sonucunda çözümlerin kısmen farkında olanlar ve farkında olmayanlar olarak iki tema ortaya çıkmıştır. Okul yöneticilerinin başka okullarda üretilen çözümlerden yararlanma ve okullar arası işbirliğine ilişkin görüşlerinin analizi sonucunda uygulama odakl, eğitim öğretim odaklı işbirliği, personel odaklı işbirliği, bilgi paylaşımı odaklı işbirliği ve örgütsel odaklı işbirliği olarak beş tema ortaya çıkmıştır.

\section{Geçerlik Güvenirlik Önlemleri}

Araştırmada görüşmelerin sürelerinin uzun tutulması, uzman incelemesi ve katılımcı geribildirimi alınması ile iç geçerlik sağlanmıştır. Araştırmanın dış geçerliğini sağlamak amacıyla, yöntem kısmında araştırmanın çalışma grubu, veri toplama aracı, araştırmanın modeli, ulaşılan verilerin çözümlenmesi gibi konular detaylı bir şekilde açıklanmıştır. Araştırmanın iç güvenirliğini sağlamak için, tutarlık incelemesi yapılmıştır. Nitel çalışmalarda araştırmanın delilli kanıtlarla desteklenmesi, dış güvenirlik ölçüsüdür. Aynı zamanda Yıldırım ve Şimşek'in (2005) belirttiği teyit incelemesi için bu araştırmada verilerin doğrulanması ve kodlamaların başka bir akademisyen tarafından da incelemesi yapılmıştır. Araştırmanın dış güvenirliğini sağlamak amacıyla, üzerinde çalışılan mevcut durum ve kullanılan yöntem ayrıntılı bir şekilde betimlenmeye çalışılmıştır. Verilerin toplanması ve analizinin ayrıntılı olarak açıklanması için çaba harcanmıştır. 


\section{Bulgular}

\section{Göçe Bağlı Olarak Karşılaşılan Sorun Alanları}

Çalışmanın ilk araştırma sorusu Okul yöneticilerinin göçe bağlı olarak karşılaştıkları sorun alanlarına ilişkin görüşleri nelerdir? şeklinde belirtilmiştir. Bu araştırma sorusunun verileri doğrultusunda elde edilen temalar Tablo 3'de verilmektedir.

Tablo 3

Göçe Bağlı Olarak Karşılaşılan Sorun Alanları

\begin{tabular}{lll}
\hline Tema & Kodlar & $N$ \\
\hline \multirow{4}{*}{ Aile ile ilgili sorun alanları } & Ders araçlarını karşılayamama- Ekonomik yetersizlik & 16 \\
& Okul aile işbirliği eksikliği & 7 \\
& Türk ailelerden gelen şikâyetler & 5 \\
& İletişim kurma sorunları & 28 \\
& Duygusal sarsıntı yaşama & 17 \\
& Öğrenci-öğrenci şiddeti sorunu & 9 \\
& Devamsızlı & 7 \\
Öğrenci sorun alanları & Okul terki & 6 \\
& Akademik başarı düşüklüğü & 6 \\
& Temizlik alışkanlığı eksikliği & 6 \\
& Bilişsel uyumsuzluk & 5 \\
& Duyuşsal uyumsuzluk & 5 \\
& İstenmeyen öğrenci davranışları & 4 \\
& Fiziki yetersizlik & 8 \\
& Öğrenci sayısını artması & 8 \\
Yapısal temelli sorun alanları & Personel eksikliği & 4 \\
& Okulların bütçe yetersizliği & 4 \\
& Okulun başarı düşüklüğ̈̈ & 2
\end{tabular}

Tablo 3 incelendiğinde göçe bağlı olarak karşılaşılan sorun alanlarına ilişkin verilerin analizi sonucunda aileye bağll, ögrenciye bağll, ögretmene bağll ve yapısal temelli sorun alanlarl olmak üzere 4 tema ve bunların 20 kodu ortaya çıkmıştır. Bu temalardan aileye bağlı sorun alanlarında en çok ekonomik yetersizlik $(n=16)$ sorun alanı olarak belirtilmiştir. Öğrenciye bağlı sorun alanlarında ise en çok iletişim kurma sorunları $(n=28)$ ile ilgili ifadeler belirtilmiştir. Yapısal temelli sorun alanında ise en çok fiziki yetersizlik ve ögrenci sayısının artması $(n=8)$ ile ilgili ifadeler belirtilmiştir. Öğretmene bă̆ll sorun alanlarında ise en çok ögrretmen- ögrenci iletişim sorunu $(n=6)$ ile ilgili ifadeler belirtilmiştir.

Analiz sonucunda okul yöneticilerinin göçe bağlı olarak karşılaştıkları sorun alanları incelendiğinde aileye bağll sorun alanlarında okul yöneticileri birtakım görüşler ifade etmişlerdir. Okul yöneticilerinin aileye bağlı sorunlar temasında Ders araçlarını karşılayamama $(n=16)$ kodu öne çıkmıştır. Bu kod ile ekonomik yetersizlik nedenli olarak öğrencilere okulda gerekli olan ders araç gereçlerinin temin edilmesinde ailelerin zorlandıkları vurgulanmaktadır. Ders araçlarını karşılayamama koduna ilişkin okul yöneticilerinden birinin görüşlerinden bir alıntı şu şekildedir:

Ailelerin birçoğu ekonomik sıkıntı çekmekte. Yoksulluk sınırında yaşam mücadelesi vermekteler.

Hal böyle olunca anne ve babanın çocuğunun eğitimine ayırdı̆̆ı zaman da az olmakta.(MY1)

Okul yöneticilerinin göçe bağlı olarak karşılaştıkları sorun alanlarında ikinci tema ögrenciye bağlı sorun alanları temasıdır. Analiz sonucunda okul yöneticilerinin ögrenciye bă̆lı sorun alanları temasında en çok İletişim kurma sorunları $(n=28)$ kodu öne çıkmıştır. İletişim kurma sorunları kodu çoğunlukla öğrencilerin Türkçe konuşamaması nedeniyle iletmek istediklerini karşı tarafa anlatamaması, sorunlara çözüm bulunamaması ve kopukluk oluşması ile ilgilidir. İletişim kurma sorunları koduna ilişkin okul yöneticilerinden birinin görüşlerinden bir alıntı şöyledir:

Karşılaştı̆̆ımız en büyük sorun dil sorunudur. Göçle gelen çocuklar ortak dil kullanamadıklarından anlatılanları anlamakta zorluk çekmektedirler. Bu anlamda eşitliği sağlamakta okula büyük görev düşmektedir. Öğretmenlerin onlarla iletişim kurmalarl zorlaşmaktadır. İletişim kurmak için hep bir aracıya (tercümana) ihtiyaç duymaktayız. (M2) 
Öğrenciye bağlı sorun alanları temasında ikinci olarak vurgulanan kod Duygusal travma yaşama $(\mathrm{n}=17)$ kodudur. Duygusal travma yaşama kodu öğrencilerin göç öncesi, göç sırasında ve sonrasında yaşadıklarından kalan duygusal etkileri içermektedir. Duygusal travma yaşama koduna ilişkin okul yöneticilerinin görüşlerinden bir alıntı şu şekildedir:

Çocukların yabancılık duyguları var. Biraz çekimser kaliyorlar. Duygusal sorunları ilk geldikleri yıllar fazlaydı. Bahçede oyun oynarken uçak ya da helikopter geçtiğinde kendileri yere atıyorlard korkudan. Üzerlerinde savaşın getirdiği psikolojik etkileri vardı. (M17)

Okul yöneticilerinin ögrenciye bağlı sorun alanları temasında ikinci olarak öne çıkan kod Öğrenci- ögrrenci şiddet $(n=9)$ kodudur. Öğrenci-ögrenci şiddet sorunu koduna ilişkin okul yöneticilerinin görüşlerinden iki alıntı şu şekildedir:

\section{Ansızın ögrrenciler parlayıp kavga edebiliyorlar ve bu esnada kemerini çıkartan öğrenciler gördüm. (M11)}

Bizim ögrrencilere göre daha kavgacılar. Bizim öğrenciler sorunlarda karşıllklı konuşabiliyorlar ama bu ögrenciler daha kavgacılar. (M15)

Ögrenciye bă̆ll sorun alanları temasında ikinci olarak vurgulanan kod Duygusal travma yaşama $(n=17)$ kodudur. Duygusal travma yaşama kodu öğrencilerin göç öncesi, göç sırasında ve sonrasında yaşadıklarından kalan duygusal etkileri içermektedir. Duygusal travma yaşama koduna ilişkin okul yöneticilerinin birinin görüşlerinden bir alıntı şu şekildedir:

Çocukların yabancıllk duyguları var. Biraz çekimser kalıyorlar. Duygusal sorunları ilk geldikleri yıllar fazlaydı. Bahçede oyun oynarken uçak ya da helikopter geçtiğinde kendileri yere atıyorlardı korkudan. Üzerlerinde savaşın getirdiği psikolojik etkileri vardı. (M17)

Okul yöneticilerinin göçe bağlı olarak karşılaştıkları sorun alanlarında üçüncü tema yapısal temelli sorun alanları temasıdır. Bu tema altında en çok vurgulanan kod Fiziki Yetersizlik $(n=8)$ kodudur. Fiziki yetersizlik kod okul yöneticilerinin göçmen öğrencilerin eğitimindeki özel gereksinimleri karşılamada yaşadığı fiziksel kaynaklı sorunlara ilişkin görüşlerini içermektedir. Fiziki yetersizlik koduna ilişkin okul yöneticilerinin görüşlerinden bir alıntı şu şekildedir:

Sinıf ayarlamamız sıkıntı oluyor tabi. Şimdi dil eğitimi için Türkçe öğretmenimiz geldi. Dil eğitimi vereceğimiz sınıf sıkıntımız var. Sinıflarımız dolu, kapasitemiz doldu. Öğrencilerimiz Türkçe derslerini kütüphanede görmek zorunda kallyorlar. Orada da tahta yok. Akıllı tahta yok. (MY5)

Okul yöneticilerinin yapısal temelli sorun alanları temasında ögrenci sayısının artması $(n=8)$ koduna ilişkin yöneticiler birtakım görüşler ifade etmişlerdir. Öğrenci sayısının artması koduna ilişkin okul yöneticilerinin görüşlerinden iki alıntı şu şekildedir:

Geçen sene 75 civarında olan Suriyeli öğrenci sayımı 120 öğrenciye yaklaşmışıtr. Bu da beraberinde sinıflardaki ögrenci sayısinın artmasina neden olmaktadır. Sirf bu sene 50 ögrrenciyi birinci sınıfa kaydını gerçekleştirdik. (M5)

Bulunduğumuz yer konumu itibarıyla çok göç alan bir noktada bulunmaktadır. Buna bağlı olarak da ögrenci sayımızda her sene sürekli bir artış olmaktadır ve bu bölgedeki tek ilkokul olmamız fiziki sorunları ve kalabalık sinıfları beraberinde getirmektedir. (M7)

Okul yöneticilerinin göçe bağlı olarak karşılaştıkları sorun alanları incelendiğinde okul yöneticileri ögrretmen temelli sorun alanlarında benzer görüşler belirtmişlerdir. Analiz sonucunda okul yöneticilerinin ögrretmen temelli sorun alanları temasında ögrenci- ögretmen iletişim eksikliği $(n=3)$ koduna ilişkin görüşleri öne çıkmıştır. Öğrenci- öğretmen iletişim eksikliği kodu öğretmenlerin göçmen öğrencilerle yaşadığı çatışmalar sonucunda iletişim kurmaktan vazgeçmesi ya da direnç göstermesine ilişkin görüşleri içermektedir. Öğrenciöğretmen iletiş̧im eksikliği koduna ilişkin okul yöneticilerinin görüşlerinden bir alıntı şu şekildedir:

Okulda göçle gelen çocuklar ne yazık ki sık slk sorun yaşattıklarından özellikle sinı öğretmenleri kendi sinıflarında bu çocukları istememektedir. Öğretmenler dil sorununu çözemedikleri için hem ögrenciyle hem de ailesiyle sorunların giderilmesi konusunda bir ilerleme sağlayamamaktadır. Bu ögrenciler bir süre sonra yok sayllmaktadirlar. (M2)

\section{Okul Yöneticilerinin Göçmen Öğrencilerin Eğitim Sürecinde Karşıllaştı̆̆ı Sorunların Nedenleri}

Çalışmanın ikinci araştırma sorusu Okul yöneticilerinin göçmen öğrencilerin eğitim sürecinde karşılaştı̆̆ sorunların nedenlerine ilişskin görüşleri nelerdir? şeklinde belirtilmiştir. Bu araştırma sorusunun verileri doğrultusunda elde edilen temalar Tablo 4'te verilmektedir. 
Tablo 4

Okul Yöneticilerinin Göçmen Öğrencilerin Eğitim Sürecinde Karşılaştı̆̆ Sorunların Nedenleri

\begin{tabular}{lll}
\hline Temalar & Kodlar & $N$ \\
\hline & Ekonomik yetersizlik & 14 \\
Aileye bağlı nedenler & Kültürel farklılıklar(çok çocuklu-kalabalık yaşama) & 6 \\
& Ailelerin düşük eğitim seviyesi & 7 \\
& Yerleşik hayata geçememe & 6 \\
& Türkçe bilmeme & 25 \\
& Devamsılık & 6 \\
Öğrenciye bağlı nedenler & Savaş travmasını yaşama- Duygusal problemler & 2 \\
& Öğrenciler arası gruplaşma-çatışma & 3 \\
& İstenmeyen öğrenci davranışları-şikayetler olması & 3 \\
& Artan göçmen öğrenci sayısı & 10 \\
\cline { 2 - 2 } Yapısal temelli nedenler & Okulların fiziki yetersizlikleri & 3 \\
& Olumsuz personel tutumları & 4 \\
& Akran denkliğinin değerlendirilememesi-bilişsel yetersizlik & 6 \\
\hline
\end{tabular}

Tablo 4 incelendiğinde okul yöneticilerinin göçmen öğrencilerin eğitimi sürecinde karşılaştıkları sorunların nedenlerine yönelik görüşlerinin analizi sonucunda aileye bağll nedenler, ögrenciye bağll nedenler ve yapısal temelli nedenler olmak üzere 3 tema ve bunların 13 kodu ortaya çıkmıştır. Bu temalardan aileye bağl nedenler temasında en çok ekonomik yetersizlik $(n=14)$ sorun nedeni olarak belirtilmiştir. Öğrenciye bağll nedenler temasında en çok Türkçe bilmeme $(n=25)$ neden olarak belirtilmiştir. Yapısal temelli nedenler temasında ise en çok artan ögrenci saylsı $(n=10)$ sorunların nedeni olarak belirtilmiştir.

Analiz sonucunda okul yöneticilerinin göçmen öğrencilerin eğitimi sürecinde karşılaşılan sorunların nedenlerine ilişkin görüş̧lerinde aileye bağll nedenler temasında ekonomik yetersizlik $(n=14)$ kodu öne çıkmıştır. Ekonomik yetersizlik kodu öğrencilerin yaşadıkları ekonomik yetersizlikler nedeniyle hem eğitimleri için gerekli ihtiyaçlarını karşılayamamaları hem de velilerin ekonomik gerekçeler nedeniyle çocuklarına yeteri ilgiyi gösterememelerine ilişkin görüşleri içermektedir. Ekonomik yetersizlik koduna ilişkin yöneticilerden birinin görüşlerinden bir alıntı şu şekildedir:

Ailelerin yaşadı̆̆ ekonomik sorunlarda eğitim sürecinde karşılaşttğımız sorunların nedenidir. Öğrencilerin kenar mahallelerde ekonomik sıkıntılar içinde yaşamaları beraberinde başarısızlı̆̆ getirmekte. (MY2)

Analiz sonucunda okul yöneticilerinin göçmen öğrencilerin eğitimi sürecinde karşılaşılan sorunların nedenlerine ilişkin görüşleri incelendiğinde ögrrenciye bağll nedenler temasında benzer görüşler belirtilmiştir. Öğrenciye bağlı nedenler teması Türkçe bilmeme $(n=25)$ kodu öne çıkmıştır. Okul yöneticilerinin öğrencilerin Türkçe bilmemesinin sorunun asıl kaynağının olduğunu belirten görüşlerine ilişkin bir alıntı şu şekilde ifade edilmiştir:

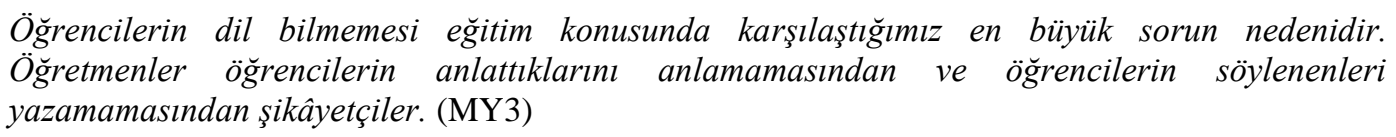

Analiz sonucunda okul yöneticilerinin göçmen öğrencilerin eğitimi sürecinde karşılaşılan sorunların nedenlerine ilişkin görüşleri incelendiğinde yapısal temelli nedenler temasında en çok vurgulanan artan ögrrenci sayısı $(\mathrm{n}=10)$ kodudur. Artan öğrenci sayısı kodu sınıfların kalabalıklaşması sonucu öğretmenlerin öğrencilere ayırdığı zamanda azalma ve bunun ders verimliliğine olan etkisine ilişkin görüşleri içermektedir Artan ögrenci saylsı koduna ilişkin okul yöneticilerinden birinin görüşlerinden bir alıntı şu şekildedir:

En temel problem bence öğrenci sayısının giderek artması. Yani bir sinıfta 3-4 Suriyeli ögrencinin olmasiyla 9-10 Suriyeli ögrrencinin olmasinın arasında çok fark var. İlk yıllarda 35-40 öğrencimiz vardl. Şu an 1. sinıfa kayıtl 113 yeni öğrencimiz var. (M16)

\section{Okul Yöneticilerinin Kullandıkları Sorun Çözüm Yolları}

Çalışmanın üçüncü araştırma sorusu Okul yöneticilerinin sorunların çözümünde hangi çözüm yollarına başvurduklarına iliş̧kin görüşleri nelerdir? şeklinde belirtilmiştir. Bu araştırma sorusunun verileri doğrultusunda elde edilen temalar Tablo 5'de verilmektedir. 
Tablo 5

Okul Yöneticilerinin Kullandıkları Sorun Çözüm Yolları

\begin{tabular}{lll}
\hline Temalar & Kodlar & $N$ \\
\hline & Bireysel görüşme yöntemi & 11 \\
Etkileşimi geliştirme & Ev ziyaretleri & 5 \\
& Okul-öğrenci- veli iletişim etkinlikleri düzenleme & 6 \\
& Sosyal ve sportif faaliyetler & 3 \\
& Rehberlik ve oryantasyon etkinlikleri & 9 \\
& Destekleme ve yetiştirme kursları & 5 \\
Eğitim & Dil kursları & 14 \\
& Aile eğitimi & 2 \\
& Akran koçluğu & 9 \\
İşbirliği geliştirme & Maddi kaynak bulma & 7 \\
& Öğrenci tercümanı kullanma & 5 \\
& Okullar arası işbirliği & 2 \\
& Kaynaştırma planlaması & 3
\end{tabular}

Tablo 5 incelendiğinde okul yöneticilerinin göçmen öğrencilerin eğitimi sürecinde karşılaştıkları sorunlara yönelik hangi çözüm yollarına başvurduklarına ilişkin görüşlerinin analizi sonucunda etkileșim, eğitim ve işbirliği geliştirme şeklinde olmak üzere 3 tema ve bunların 13 alt teması ortaya çıkmıştır. Bu çözüm yollarından etkileşim geliştirme temasında en çok bireysel görüş̧me yöntemi $(n=11)$ kodu ile ilgili ifadeler vurgulanmıştır. Eğitim temasında en çok dil kursları $(n=14)$ kodu ile ilgili ifadeler vurgulanmıştır. Işs birliği geliş̧tirme temasında ise en çok akran koçluğu $(n=9)$ kodu ile ilgili ifadeler vurgulanmıştır.

Analiz sonucunda okul yöneticilerinin göçmen öğrencilerin eğitimi sürecindeki sorunların çözüm yollarına ilişkin görüşleri incelendiğinde etkileşim gelişstirme temasında bireysel görüşme yöntemi kodu en çok vurgulanmıştır. Bireysel görüşsme yöntemi kodu $(n=11)$ aile ve öğrenci ile görüşmeler yaparak karşılaşılan sorunlara çözümler bulmaya çalıştıklarına ilişkin görüşleri içermektedir. Bireysel görüşme yöntemi koduna ilişkin okul yöneticilerden birinin görüşlerinden bir alıntı şu şekildedir:

Sorunu birebir iliş̧ki ile konuşarak çözüyoruz. Bu öğrenci ile de olabiliyor, okula getirtebilirsek veli ile de olabiliyor. (M1)

Okul yöneticilerinin göçmen öğrencilerin eğitimi sürecindeki sorunların çözüm yollarına ilişkin eğitim temasında en çok dil kursları $(n=14)$ kodu öne çıkmıştır. Dil kursları kodu okul yöneticilerinin daha çok PICTES (Suriyeli Çocukların Türk Eğitim Sistemine Entegrasyonunun Desteklenmesi Projesi) programı kapsamında açılan dil veya yetiştirme kursları aracılı̆̆ıyla göçmen öğrencilerin eğitimlerine destek olmaya çalıştıklarına ilişkin görüşleri içermektedir. Dil kursu koduna ilişkin okul yöneticilerden birinin görüşlerinden bir alıntı şu şekildedir:

Türkçe kursları veriyoruz. Suriyeli okuma yazma bilmeyen öğrenciler sabahçı ise öğleden sonra, öğlenci ise sabahlart 2'şer saat kursa alıyoruz. PICTES programı kapsamında onları kursa aliyoruz. Türkçe ögreticiler tarafindan bu şekilde normal derslere destek oluyoruz. (M7)

Okul yöneticilerinin göçmen öğrencilerin eğitimi sürecindeki sorunların çözüm yollarına ilişkin görüşlerinde işbirliği geliştirme temasında en çok akran koçluğu $(n=9)$ kodu vurgulanmıştır. Akran koçluğu kodu öğrencilerin sosyalleşmelerinin sağlanması ve dil öğrenimlerinin hızlanması amacıyla Türk öğrencilerin görevlendirilmesine ilişkin görüşleri içermektedir. Akran koçluğu koduna ilişkin okul yöneticilerinden birinin görüşlerinden bir alıntı şu şekildedir:

Duygusal sorunların çözz̈mü konusunda okulumuzda başlattığımız yabancı öğrenciyle arkadaşlı, akran arkadașll̆̆̆ kurarak her Suriyeli öğrenci için iki öğrenci görevlendirdik. Bunlara destek olmalar, beraber oynamaları, beraber gezmeleri, basit kelimeler cümleler kullanmalarl, bunları öğretmeleri ve bu vasitasiyla bir iletişim köprüsü kurmaya çalıştı. Öğrencilerin Türkçe öğrenmelerini gelişstirmek amaçlı böyle bir çalışma gerçekleştirdik. Yararı da oldu. (M10)

Göçmen Öğrencilerin Eğitim Sürecinde Karşılaşılan Sorunlara Yönelik Farklı Okulların Çözümleri

Çalışmanın dördüncü araştırma sorusu Okul yöneticilerinin gö̧̧men ögrrencilerle ilgili sorunlara yönelik başka okullarda üretilen çözümlerle ilgili görüşleri nelerdir? şeklinde belirtilmiştir. Bu araştırma sorusunun verileri doğrultusunda elde edilen temalar Tablo 6'da verilmektedir. 
Tablo 6

Okul yöneticilerinin göçmen öğrencilerle ilgili sorunlara yönelik başka okullarda üretilen çözümlerine ilişkin görüşleri

\begin{tabular}{lll}
\hline Temalar & Kodlar & $N$ \\
\hline & Düzensiz aralıklarla bilgilenme & 16 \\
& Bilgisiz olma & 7 \\
& Bireysel iletişim kurma & 1 \\
& Sosyal faaliyetler düzenleme & 1 \\
Çözümlerin farkında olmayanlar & Öğrenci tercümanı kullanma & 1 \\
& Özel alt sinıflar oluş̧urma & 1 \\
& Göçmen rehber öğretmen çalıştırma & 1 \\
& İnsan ilişkilerine önem verme & 1 \\
& Fiziki alanları verimli kullanma & 1 \\
& İnsan kaynağının ortak kullanımı & 1 \\
Çözümlerin kısmen farkında & Benzer çözümleri uygulama & 7 \\
olanlar & Fiziki alanların ortak kullanımı & 2 \\
& Dil kursları düzenleme & 3
\end{tabular}

Tablo 6 incelendiğinde yöneticilerinin göçmen öğrencilerle ilgili sorunlara yönelik başka okullarda üretilen çözümlerle ilgili görüşlerinin analizi sonucunda çözümlerin farkında olmayanlar ve çözümlerin kısmen farkında olanlar olmak üzere 2 tema ve 13 alt teması ortaya çıkmıştır. Çözümlerin farkında olmayanlar temasında en çok düzensiz aralıklarla etkileşim sonucu bilgilenme $(n=16)$, bilgisiz olma $(n=7)$ kodlar1; çözümlerin klsmen farkında olanlar temasında en çok benzer çözümleri uygulama $(n=7)$ kodu öne çıkmıştır.

Analiz sonucunda okul yöneticileri göçmen öğrencilerle ilgili sorunlara yönelik başka okullarda üretilen çözümlere ilişkin görüşleri incelendiğinde çözümlerin farkında olmayanlar temasında düzensiz aralıklarla etkileşim sonucu bilgilenme $(n=16)$ kodu öne çıkmıştır. Düzensiz aralıklarla etkileşim sonucu bilgilenme kodu okul yöneticilerinin başka okullarla iletişim halinde olmadıkları zaman zaman dolaylı olarak bilgiler edinmelerine ilişkin görüşleri içermektedir. Düzensiz aralıklarla etkileşim sonucu bilgilenme koduna ilişkin okul yöneticilerinden birinin görüşlerinden bir alıntı şu şekildedir:

Diğer okullarla iletişimimiz okul müdürleri ile çeşitli sebeplerle bir araya geldiğimizde oluyor. Bunun dışında fazla bilgi alışverişimizin olduğu söylenemez. İşin doğrusu her koyun kendi bacağından asılır misali her okul kendi sorununa kendi çözüm bulmaya çalışıyor. Tabi daha öncede bahsettiğim gibi toplant, tören vb. nedenlerle diğer okul müdürü arkadaşlarla bir araya geldiğimizde sorunları görüşüyoruz. Başta da dediğim gibi herkes kendi çözümünü kendi üretiyor. (M1)

Okul yöneticilerinin göçmen öğrencilerle ilgili sorunlara yönelik başka okullarda üretilen çözümlere ilişkin görüşleri çözümlerin kısmen farkında olanlar temasında benzer çözümleri uygulama $(n=7)$ kodu en çok vurgulanmıştır. Benzer çözümleri uygulama kodu yöneticilerin sorunlara birbirlerinin farkında olmasalar da benzer çözüm yolları uygulamaya koyduklarına ilişkin görüşleri içermektedir. Benzer çözümleri uygulama koduna ilişkin okul yöneticilerinden birinin görüşlerinden bir alıntı şu şekildedir:

Her okul karşılaştığl sorunlar kendi yöntemleriyle çözüm üretiyor. Bulunduğumuz çevrede zaten bütün okullarda Suriyeli ögrenci var bizim kadar saylları yok çünkü kapasiteleri belli onlar da karşılaştıkları sorunlar da aynı bizim yöntemlerimizi uyguluyorlar. (M18)

\section{Farklı Okulların Çözümlerinden Yararlanma ve Okullar Arasında İş Birliğinin Sağlanması}

Çalışmanın beşinci araştırma sorusu Okul yöneticilerinin sorunların çözümü konusunda başka okullarda üretilen çözümlerden nasıl yararlanılabilecĕ̆i ve okullar arasında iş birliğinin nasıl săglanabileceğine ilişkin görüşleri nelerdir? şeklinde belirtilmiştir. Bu araştırma sorusunun verileri doğrultusunda elde edilen temalar Tablo 7'de verilmektedir.

Tablo 7 incelendiğinde okul yöneticilerinin sorunların çözümü konusunda başka okullarda üretilen çözümlerden nasıl yararlanılabileceği ve okullar arasında iş birliğinin nasıl sağlanabileceğine ilişkin görüşlerinin analizi sonucunda 5 tema ve 14 alt tema ortaya çıkmıştır. Bu görüşler sonucu oluşan uygulama odaklı işbirliği temasında en çok toplantılar yaparak bilgi alış verişinde bulunma $(n=14)$ koduna ilişkin ifadeler vurgulanmıştır. Ĕ̆itim-ögretim odaklı işbirliği temasında en çok kardeş okul $(n=4)$ kodu belirtilmiştir. Personel odaklı iş birliği geliştirme temasında ise en çok bakanlı̆̆ın bilgi paylaşımı konusunda girişimci olması $(n=4)$ kodu konusunda görüş belirtilmiştir. Bilgi paylaşımı odaklı temasında en çok elektronik ortamlarda bilgi alış verişi $(n=3)$ 
kodları vurgulanmıştır. Örgütsel odakl işbirliği temasında ise okul yöneticileri en çok fiziki alanların ortak kullanımı $(n=6)$ kodu konusunda görüş belirtmişlerdir.

Tablo 7

Okul Yöneticilerinin Başka Okullarda Üretilen Çözümlerden Yararlanması ve Okullar Arasında İş Birliğinin Sağlanması

\begin{tabular}{lll}
\hline Tema & Kodlar & $N$ \\
\hline $\begin{array}{l}\text { Uygulama odaklı } \\
\text { işbirliği }\end{array}$ & Toplantılarla deneyim paylaşımı (deneyim-uzmanlık) & 14 \\
Eğitim öğretim & Ortak sosyal- sportif faaliyetler düzenleme & 3 \\
odaklı ş̧birliği & Kardeş okul & 4 \\
& Bölgesel kurslar düzenleme & 3 \\
Personel odaklı & İnsan kaynağının ortak kullanımı & 2 \\
işbirliği & Rehberlik servisleri arasında iş birliği & 1 \\
& Ögretmenleri teşvik etme & 2 \\
Bilgi paylaşımı & Bakanlığın çalışanlarla bilgi paylaşımı & 4 \\
odaklı işbirliği & Üretilen çözümler için bilgi bankası oluşturma & 2 \\
& Elektronik ortamlarda bilgi alışverişi & 3 \\
Örgütsel odaklı & Fiziki alanların ortak kullanımı & 6 \\
işbirliği & MEB Bilgilendirme merkezleri-birimleri kurma & 2 \\
& Okullar arası komisyonlar kurma & 5 \\
\hline
\end{tabular}

Analiz sonucunda okul yöneticilerinin başka okullarda üretilen çözümler ve okullar arası işbirliğinin nasıl sağlanabileceğine yönelik görüşleri uygulama odakl işsirliği temasında toplantılar yapılarak bilgi alış verişinde bulunulmalı $(n=9)$ kodu en çok vurgulanmıştır. Toplantılar yapılarak bilgi alış verişinde bulunulmalı kodu okul yöneticilerin göçmen öğrencilerin eğitimi sürecinde karşılaşlan sorunlar ve sorunların çözümüne yönelik yaptıkları uygulamalar ve sorunların çözümünde farklı olarak nelerin yapılabileceğini tartışmak, fikir alış verişleri yapmak amacıyla belli aralıklarla bir araya gelmelerine ilişkin görüşleri içermektedir. Toplantılar yapılarak bilgi alış verişinde bulunulmalı koduna ilişkin okul yöneticilerinden birinin görüşlerinden bir alıntı şu şekildedir:

Bir kere göç konusunda göçün çok yaşandiğı okullarda bir komisyonun toplanması gerekir. Çünkü göç konusu önemli bir konu ülkenin önemli bir sorunu tek bir okulun bunun üstesinden gelmesi mümkün değil. Yaptı̆̆ çalışmaları anlatabileceği paylaşabileceği ortamların yaratılması gerekir. Neler yapılabilir konusunda gö̧ alan okulların bir araya gelmesi lazım özellikle bizim bulunduğumuz semtlerde müdürler sürekli bilgi alışverişsinde bulunmall. (M6)

Analiz sonucunda okul yöneticilerinin başka okullarda üretilen çözümler ve okullar arası işbirliğinin nasıl sağlanabileceğine yönelik görüşlerinde ĕgitim ögrretim odakl işbirliği temasında kardeş okul ve bölgesel kurslar kodları en çok vurgulanmıştır. Kardeş okul kodu karşılaşılan sorunların çözümünde fiziki alanların ortak kullanımı, öğrencilerin gelişîm süreçlerinin takibi gibi konulara ilişkin okulların işbirliği yapabileceğine ilişkin görüssleri içermektedir. Kardeş okul koduna ilişkin okul yöneticilerinden birinin görüşlerinden bir alıntı şu şekildedir:

İlk ve ortaokullar kaylt alanlarına göre kardeş okul olmaları ve ilk ve ortaokullar ögrrencinin gelişimini beraber takip etmeliler. Ĕger ögrenci kendini geliş̧tirmemişse yeteri kadar dil ögrenmemişse bu ögrrenciler geçici eğitim merkezlerine yönlendirilmelidir. (M3)

Analiz sonucunda okul yöneticilerinin başka okullarda üretilen çözümler ve okullar arası işbirliğinin nasıl sağlanabileceğine yönelik görüşlerinde personel odaklı işbirliği temasında Bakanlı̆̆ın bilgi paylaşımında bulunması kodu $(n=4)$ en çok vurgulanmıştır. Bakanlığın bilgi paylaşımında bulunması kodu okul yöneticilerinin Bakanlık nezdinde yaptığı çalışmaları uygulamaya daha hızlı koyabileceklerini düşündükleri için Bakanlığın bilgi paylaşımı konusunda istekli olmasına ilişkin görüşleri içermektedir. Bakanlığın bilgi paylaşımında bulunması koduna ilişkin okul yöneticilerinin görüşlerinden alıntılar şu şekildedir:

MEB öğretmenlerin deneyimlerini belli platformlarda paylaşmalarına olanak sağlayabilir. (M1)

Bizim çözüm önerilerimiz yerelde karşılık bulsa da bunu genele yayllması zaman alabilir. Bizim önerilerimizin Bakanlık nezdinde çalışmaları 1-2 yılı bulabilir. (M9)

Okul yöneticilerinin başka okullarda üretilen çözümler ve okullar arası işbirliğinin nasıl sağlanabileceğine yönelik görüşlerinde bilgi paylaşımı odakl işbirliği temasında elektronik ortamda bilgi alış veriş̧i $(n=3)$ kodu 
en çok vurgulanmışırı. Elektronik ortamda bilgi alış verişi kodu okul yöneticilerin hızlı iletişim kurabilmek, sorunlar ve çözümleri hakkında bilgi sahibi olmanın önemine ilişkin görüşleri içermektedir. Elektronik ortamda bilgi alış verişi koduna ilişkin okul yöneticilerinden birinin görüşlerinden bir alıntı şu şekildedir:

\section{Elektronik ortamda bir site kurulup yapılan iyi çalışmalar bu sitede paylaşılabilir. (M15)}

Okul yöneticilerinin başka okullarda üretilen çözümler ve okullar arası işbirliğinin nasıl sağlanabileceğine yönelik görüșlerinde örgütsel odaklı işbirliği temasında fiziki alanların ortak kullanımı $(n=6)$ kodu ile ilgili en çok vurgulanmıştır. Fiziki alanların ortak kullanımı kodu, okul yöneticilerinin, farklı okul yöneticileri iletişim kurarak başka okulların spor salonu, bahçe, derslik, vb. fiziksel alanlarının ortak kullanımına ilişkin görüşleri içermektedir. Fiziki alanların ortak kullanımı koduna ilişkin okul yöneticilerinin görüşlerinden iki alıntı şu şekildedir:

\section{Fiziki koşulları iyi olan okullar ile olmayan okullar mekânların ortak kullanımı konusunda işbirliği yapabilirler. (M2)}

Şu anda okulumda bulunan üç dersliği yakınımızda bulunan bir okulun öğrencilerine tahsis ettik. $B u$ şekilde iş birlikleri devam ettirilebilir. (M15)

\section{Sonuç ve Tartışma}

Araştırmanın bulguları, amacı rehberliğinde tartışılmış ve kuramsal alt yapı doğrultusunda yorumlanmıştır. Bu araştırma ile okul yöneticilerinin göçmen öğrencilerin eğitimi sürecinde karşılaştıkları sorunlar ve bu sorunların çözümüne yönelik işbirliği önerileri incelenmeye çalışılmıştır. Araştırmanın birinci sorusu doğrultusunda, göçe bağlı olarak karşılaşılan sorun alanlarına ilişkin verilerin analizi sonucunda aileye bağlı, öğrenciye bağll, öğretmene bağlı ve yapısal temelli sorunlar temaları ortaya çıkmıştır. Bu araştırmadaki bulgular, Uzun ve Bütün'ün (2016), İnce (2016), Akbıyık ve Duygu (2016) ile İstanbul Bilgi Üniversitesi Çocuk Çalışmaları Birimi'nin (2015) bulgularını destekleyen bulgular içermektedir. Uzun ve Bütün'ün (2016), bulgularına göre öğretmenlerin göçmen öğrencilerin dillerini bilmedikleri için bu öğrencilerin aileleri ile iletişim kurmakta zorlandıkları ve bundan dolayı öğrencinin okulda yaşadığı sorunların çözümsüz kalmaya devam ettiği bulgusuna ulaşmıştır. İnce (2016) bulgularına göre, göçmenlerin dil problemi devam ederek aileler ile okul arasındaki iletişimin sağlanmamasına ve öğrencilerin dersleri tam olarak anlamamasına neden olmaktadır. Akbıyık ve Duygu'nun (2016) bulgularına göre, göçmenlerle iletişim kurmada zorlanma ifadelerinin ana sebeplerinin başında özellikle her iki tarafında dil eksikliği gelmektedir. İstanbul Bilgi Üniversitesi Çocuk Çalışmaları Birimi'nin (2015) bulgularına göre, okullara kaydolan Suriyeli öğrenciler dil engeliyle okula başladıkları andan itibaren karşılaşmakta ve bir şekilde bu durumla mücadele etmek zorunda kalmakta olduğu bulgusuna ulaşmıştır. Ayrıca bu araştırmanın öğrencilerin sosyal iliş̧ki kurmada yaşadığı sorunlar temasını destekleyen bulgusunda ise Türkiyeli öğrenciler ile Suriyeli öğrenciler arasında iletişimin kısıtlı olduğu, bu yüzden bu iki öğrenci grubu arasında arkadaşlık kurulamadığı ve bu durumdan da Suriyeli öğrencilerin etiketlenerek dışlandığını tespit etmiştir. Uzun ve Bütün'ün (2016) yine bu araştırmayı destekleyen bulgularına göre, farklı dilin neden olduğu diğer bir olumsuzluğun ise öğretmenlerin göçmen çocukları sınıflarında istememesi şeklinde olduğu, Türk ailelerin Suriyeli sığınmacılara karşı olumsuz tutumları olduğunu bulgulamıştır. Başarır ve arkadaşları da (2014) öğretmenlerin çok kültürlü eğitim algılarını incelediği araştırmasında derslerinde çok kültürlü eğitimi uygulayan öğretmenlerin görüşlerine göre, derslerde karşılaşılan sorun nedenlerinden biri olarak ailelerin önyargıll olması sonucuna ulaşmıştır. Yine Emin (2016) ve Bozan (2014) araştırmadaki ekonomik yetersizlik ve devamsızlık temalarını destekleyen bulgularında, lise çağındaki gençlerden okula devam eden öğrenci sayısının az olduğu ve lise çağındaki bu öğrencilerin, ebeveynlerinin yüksek olmayan ekonomik seviyede olması sebebiyle bu öğrencilerin okullarına devam etmek yerine çalışarak ailelerine ekonomik katkı sağlamak zorunda kaldığı sonucuna ulaşmıştır. Ancak bu araştırmanın bulgularında yer alan tercüman ve rehber öğretmen eksikliği temalarıyla ilgili olarak, Okul yöneticilerinin büyük bir kısmının İlçe Milli Eğitim Komisyonu'ndan tercüman isteğinde bulunarak okullarına tercüman görevlendirilmesini sağlayabileceklerine dair bilgilerinin olmadıklarını ve rehber öğretmenlerden Suriyeli öğrencilerin çoğu zaman destek alamadıkları belirlenmiştir. Bunu Sakız'ın (2016) okul yöneticilerinin öğrenciler için daha kapsamlı çalışmaların gerektiği ve okullarında bulunan rehberlik ve psikolojik danışmanlık servislerinin bu çalışmalar için yeterli olmadığını bulgusuyla desteklediği görülmektedir. Alanyazın ve bulgular incelendiğinde göçe bağlı olarak oluşan sorun alanlarının paralel olmasının nedeni sorunların çözümü konusunda atılan adımların henüz yetersiz olması olabilir.

Araştırmanın ikinci sorusu doğrultusunda okul yöneticilerinin göçmen öğrencilerin eğitim sürecinde karşılaştı̆̆ sorunların nedenlerine ilişkin verilerin analizi sonucunda en çok dil bilmeme, ekonomik yetersizlik ve artan öğrenci sayıları kodları eğitimde karşılaşılan sorunların nedeni olarak belirtilmiştir. Akbıyık ve Duygu'nun (2016) duygusal problemler alt temasını destekleyen bulgusunda göçmenlerde hissedilen en büyük problem olarak en çok dil sorunu, daha sonra adaptasyon konusunda yaşanan sorunların çözümü ile ilgili gerekli tedbirlerin alınmaması tespit edilmiştir. Sakız (2016) yaptığı araştırmada yine bu araştırmanın bulguları arasında 
yer alan artan öğrenci sayısı alt temasını destekleyen bulgusuna göre yöneticilerin çoğunun son yıllardaki artan göç hareketleri nedeniyle oluşan çeşitliliğin mevcut öğrencilerin düzenini aksatırken, bu farklılıkların kendi okullarının akışını bozduğu belirlenmiştir. Manço (2002) çalışmasında eğitim alanındaki sorunların bir bölümünün, anaokulu çağındaki devamsızlıklarından kaynaklandığını, anne babaların çalışma hayatı ve akşam yatı̧ ve güne başlama saatleri, okula devam eden çocukların eğitim kalitesine etki edebileceğini ve göçmen ailelerinin yaşayabilecekleri ekonomik sıkıntıların, başarısızlığı körüklediğini bulgulayarak araştırma bulgularını desteklediği görülmektedir. Hacıfazlığlu, Karaırmak ve Öztabak(2015) araştırmalarında anne babaların eğitim seviyelerinin öğrencinin akademik başarı üzerinde etkili olduğu bulgusuna ulaşmışlardır. Ayrıca İnce'de (2016) araştırmasındaki göçmen çocuklarının özellikle de Türk göçmen çocuklarının başarı düzeyi düşük okullara gitmesi, devamsızlık oranının yüksek olmasının üzerinde ailenin sosyo-ekonomik düzeyinin düşük olması gibi ailevi faktörler etkili olduğu bulgusu ile İstanbul Bilgi Üniversitesi Çocuk Çalışmaları Birimi’nin (2015) Suriyeli göçmen çocukların okullara devam etme hakkına ilişkin eğitim sistemi içinde görevli çalş̧anların tutumları da birbirine çok benzememektedir. Bu çalışanlardan bazıları bunu eğitim hakkı olarak değerlendirirken, büyük bir çoğunluğu bunu Türkiye devletinin Suriyelilere sunduğu bir 'lütuf' olarak gördüğü gözlemlenmiștir ve rehber öğretmenlerin donanımlı ve istekli olmayışları bulgusuyla araştırmayı desteklemektedir. Alanyazın ve araştırmanın bulgularının nedeni göçmen öğrencilerin sorunlarına yönelik çalışmaların yetersiz kalmasından ve okul yöneticilerinin önlem alma konusunda istekli olmamalarından veya sahip oldukları sosyal sermayelerinin zayıf olmasindan kaynaklanabilir.

Araştırmanın üçüncü sorusu doğrultusunda okul yöneticilerinin göçmen öğrencilerin eğitimi konusunda karşılaştıkları sorunlara uyguladıkları çözüm yollarının en çok dil kursları düzenleme ile ilgili olduğu ortaya çıkmıştır. Bu araştırmada elde edilen okul- öğrenci - veli iletişim etkinlikleri alt temasının azlığı ve öğrenci tercüman kullanma bulguları ile Bilgi Üniversitesi Çocuk Çalışmaları Birimi'nin (2015) yapmış olduğu çalışmanın okullarda Suriyeli ailelerin okulla ilişkilerinin zayıf olması ve okul idarecilerinin çoğunluğu İlçe Milli Eğitim Komisyonu'ndan talep ederek tercüman görevlendirilmesini sağlayabileceklerinden haberdar değildir bulgusunu destekler niteliktedir. Alanyazın ve bu araştırmanın bulguları doğrultusunda okul yöneticilerin sorunların çözümü konusunda birbirinin tekrarı uygulamalarla sorunlarına çözüm aramalarının nedeni mevzuat ve eğitim yönetimi uzmanlık bilgisi ile yönetici yeterliliklerindeki zayıflık olabilir.

Araştırmanın dördüncü sorusu doğrultusunda okul yöneticilerinin göçmen öğrencilerin sorunlarına yönelik başka okullarda üretilen çözümlerin konusundaki bilgilerinin sınırlı olduğu ve en çok düzensiz aralıklarla etkileşim sonucu bilgilendikleri ortaya çıkmıştır. Alanyazında bu araştırma bulgusunu doğrudan destekleyen bir araştırma bulgusuna erişilememiştir. Araştırmanın bulguları doğrultusunda okul yöneticilerinin karşılaştıkları sorunlarla ilgili kendi çözümlerini üretmeye çalıştıkları farklı okullardaki çözüm yollarıyla çok da ilgilenemedikleri söylenebilir. M13'ün "Başka okullardaki üretilen çözümleri bilmiyorum biz burada kendi yağımızla kavrulmayı öğrendik" demesi ve M14 numaralı katılımoının "Sorunların çözümü konusunda diğer okullarında çokta fazla iletişimimiz olmadı kurt misali boynun niye kalın kendi sorunumu kendim çözdüğ̈̈̈m için misali okulumuzda da fazla sorun yaşamadığım için dışarıya çok da bakmadık" demesi bu ifadeyi desteklemektedir. Alanyazın ve bu araştırmanın bulguları doğrultusunda okul yöneticilerinin göçmen öğrencilerin eğitiminde okullar arası işbirliğini kullanamamaları karşılaşılan sorunlara bütüncül ve çok yönlü bir bakış açısıyla çözüm üretmediklerinin göstergesi olabilir.

Araştırmanın beşinci sorusu doğrultusunda okul yöneticilerinin göçmen öğrencilerin eğitimi sürecinde karşılaşılan sorunların çözümü konusunda başka okullarda üretilen çözümlerden nasıl faydalanılabileceği ve okullar arası işbirliğinin nasıl geliştirilebileceği yönelik görüşlerinin analizi sonucunda en çok toplantılar yapılarak bilgi alış verişinde bulunulması kodları belirlenmiştir. Öte yandan Aydoğan'a (2013) göre örgütler, çevrelerinden bağımsız düşünülmeyecek açık sistemlerdir ayrıca, yaşama ve gelişmeleri çevrelerine uyum sağlayabilme kapasitelerine bağlıdır. Ayrıca yeni kurumsalcılar çevrelerine uyum sağlamış örgütlerin güçlü bir imaja sahip olacaklarını böylece ihtiyaçları olan kaynaklara daha kolay ulaşabileceklerini ve örgüt olarak birbirlerine benzeyeceklerini vurgulamaktadırlar (Bolat ve Seymen 2006). Araştırmanın bulguları ışığında okul yöneticilerinin işbirliği konusunda istekli olduklarını ancak iş birliğini nasıl gerçekleştirebilecekleri konusunda yeterli bilgilerinin olmaması nedeniyle yönlendirilmeye ihtiyaçlarının olduğu, deneyimlerin paylaşımı konusunda bir koordinasyon ihtiyacı olduğu anlaşılmaktadır. Alanyazın ve bu araştırmanın bulguları doğrultusunda okul yöneticilerinin göçmen öğrencilerin eğitimi sürecinde sınırlı sayıda çözüm yolları üretmiş olmaları okul yönetiminin kuramsal özellikleri konusunda yeterli bir bilgiye sahip olmadıkları ve işbirliği geliştirebilme konusunda sosyal sermayelerinin farkında olmamaları ya da sosyal sermayeyi kullanamamalarının göstergesi olabilir.

Sonuç olarak araştırmanın bulguları doğrultusunda hem uygulayıcılara hem de araştırmacılara yönelik öneriler geliştirilmiştir. Bu araştırmada, okul yöneticilerin göçmen öğrencilerin eğitimi sürecinde karşılaştıkları sorunlar ve bu sorunların çözümü için okullar arası işbirliğinin geliştirilmesine ilişkin elde edilen bulgulara dayalı öneriler şunlardır: 
1. Göçe bağlı olarak karşılaşılan sorun alanlarında en çok dil bilmemeye bağlı iletişim sorunları, ekonomik yetersizlik ve ögrencilerin duygusal travma yaşamaları sorun alanı olarak belirtildiğinden okullar ve sosyal hizmetler müdürlükleri işbirliği kurarak ekonomik durumu iyi olmayan öğrencilere yönelik maddi yardımlar sağlanabilir, okullarda ailelerle olan bütünleşme ve kaynaşmaya yönelik etkinlikler düzenlenebilir.

2. Okul yöneticilerinin görüşlerinde göçmen öğrencilerin eğitim sürecinde karşılaştı̆̆ sorunların nedenleri olarak en çok dil bilmeme, ekonomik yetersizlik ve artan öğrenci sayıları belirtildiğinden artan sınıf mevcutlarının düşürülmesi için Milli Eğitim Bakanlığı planlamalar yapmalı ve öğrencilerin belli okullara olan yı̆̆ılmalarının önüne geçilmelidir.

3. Okul yöneticilerinin göçmen öğrencilerin eğitimi konusunda karşılaşılan sorunlara yönelik en çok dil kursları aracılığıyla çözüm getirmeye çalışmaları nedeniyle göç alan bölgelerdeki okullarda öğrencilere yönelik yapılan dil kurslarına ve destekleme-yetiştirme kurslarına devam edilebilir.

4. Okul yöneticilerinin göçmen öğrencilerin sorunlarına yönelik başka okullarda üretilen çözümler konusunda düzensiz aralıklarla etkileşimler sonucu bilgi edinmeleri ve bire bir iletişim kurarak çözüm üretmeye çalışmaları nedeniyle göç alan bölgelerde çalışan öğretmenler ve okul yöneticilerinin sorunlara karşı geliştirdikleri çözümlerin farklı okullar arasında paylaşımı konusunda teşvik edilerek bilgi havuzu oluşturulması yararlı olabilir.

5. Okul yöneticilerinin göçmen öğrencilerin eğitimi sürecinde karşılaşılan sorunların çözümü konusunda başka okullarda üretilen çözümlerden faydalanma ve okullar arası işbirliğinin geliştirilmesi konusunda en çok toplantılar yapılarak bilgi alış verişinde bulunulması nedeniyle Rehberlik ve Araştırma Merkezi Müdürlüklerine göç birimi kurularak okullarda karşılaşılan sorunlar için bilgi bankaları kurulabilir ve bu bilgiler 1şığında sorunlara çözümler getirilebilir, okul yöneticilerine işbirliği geliştirme ve yönetici yeterlilikleri konusunda hizmet içi eğitimler verilebilir, Milli Eğitim Bakanlığı okullar arası işbirliği protokolü çerçevesi oluşturabilir ve bu protokollerin okullar arasında yaygınlaştırılmasının takibi yapılabilir. Ayrıca göçmen öğrencilerin eğitim sürecinde karşılaşılan sorunların çözümüne yönelik okullar arası işbirliğinin geliştirilmesini okul yöneticilerinin görüşlerine göre inceleyen bu çalışmanın benzeri öğretmen çalışma grubu ile yapılabilir. 


\section{Kaynakça/References}

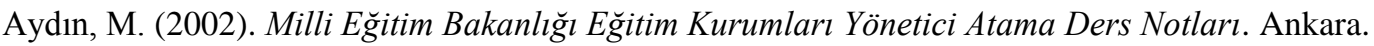

Aydoğan, İ. (2013). Örgüt ve yönetim kuramları. İçinde N. Can (Ed.), Kuram ve uygulamada eğitim yönetimi. (ss.1-27). Ankara: Pegem Akademi.

Başarır, F., Çetin, A. ve Sarı, M. (2014). Öğretmenlerin çok kültürlü eğitim algılarının incelenmesi. Pegem Ĕ̌itim ve Öğretim Dergisi, 4(2), 91-110.

Bolat, T. ve Seymen, O. A. (2006). Yönetim ve örgüt düşüncesinde kurumsalcılık, yeni kurumsalcılık ve kurumsal eşbiçimlilik. Fırat Üniversitesi Sosyal Bilimler Dergisi, 16(1), 223-254.

Bütün, E. ve Uzun Mercan, E.(2016). Okul öncesi eğitim kurumlarındaki Suriyeli sığınmacı çocukların karşılaştıkları sorunlar hakkında öğretmen görüşleri. Uluslararası Erken Çocukluk Eğitimi Dergisi, 1(1), $72-83$

Bozan, İ., (2014). Türkiye'de iç göç hareketleri ve göçün eğitim üzerindeki etkisi: bir durum çalışması. (Yayımlanmamış yüksek lisans tezi). Akdeniz Üniversitesi Eğitim Bilimleri Enstitüsü, Antalya

Çatalbaş, G., Sarıtaş, E.ve Şahin, Ü. (2016). İlkokullarda yabancı uyruklu öğrencilerle karşılaşılan sorunlar. Pamukkale Üniversitesi Sosyal Bilimler Enstitüsü Dergisi, 25(1), 208-229.

Duygu, H.ve Akbıyı,, Y. (2016). Çok kültürlü sosyo-kültürel ortamda barlş içinde yaşayabilme:Alanya örneği.Abant İzzet Baysal Üniversitesi Eğitim Fakültesi Dergisi, 16, (USBES Özel Say1 II) 1255-1277.

Eğitim Bir Sen. (2017). Türkiye’de Suriyeli Çocukların Eğitimi. Ankara http://www.ebs.org.tr/ebs_files/files/yayinlarimiz/Suriye_Rapor_TURKCE_pdf. adresinden elde edildi.

Emin, M. N. (2016). Türkiye'deki Suriyeli çocukların eğitimi temel eğitim politikaları. Siyaset, Ekonomi ve Toplum Araştırmaları Vakfi. Sayı: 153

Ereş, F. (2017). Türkiye'de göçmen eğitimi sorunsalı ve göçmen eğitiminde farklılığın yönetimi. Çankırı Karatekin Üniversitesi Sosyal Bilimler Enstitüsü Dergisi, 6(2), 17-30.

Goes, J. B., \& Park, S. H. (1997). Interorganizational linkages and innovation: The case of hospital services, Academy of Management Journal, 40, 673-96.

Göç İdaresi Daire Başkanlığ̣ (2017). 2016 Türkiye Göç Raporu. Ankara. http://www.goc.gov.tr/files/files/2016_goc_raporu_.pdf adresinden elde edildi.

Göksoy, S. (2013). Okul çevre ilişkileri. İçinde N. Can (Ed.), Kuram ve uygulamada eğitim yönetimi (ss. 285299). Ankara: Pegem Akademi.

Gulick, L. H. (1937). Notes to the theory of organizations. with specific reference to government. In L. H. Gulick and L. F. Urwick (eds.) Papers on the Science of Administration. New York: A.M. Kelley.

Hacıfazlıŏlu, Ö.,Karaırmak, Ö., Öztabak, M. (2015). Göç olgusu bağlamında lise öğrencilerinin aile profilleri ve akademik başarı durumları. Hasan Ali Yücel Ĕgitim Fakültesi Dergisi, 12-2(24), 81-97.

İnce, C. (2016). Türkiye bağlamında dış göçler, eğitim sorunu ve toplumsal konumun yeniden üretimi. Karadeniz, 36, 293-306.

Katz, D. ve Kahn, R. (1977). Örgütlerin toplumsal psikolojisi. TODAİE Yayın No: 167. Ankara

Keleş., H. (2012). Sosyal sermaye. Eğitim Yayınevi. Konya

Kılıç, F. ve Yıldız, M. (2013). Göçle gelen okul öncesi çocukların ilk okuma yazma becerilerine ilişkin 1. sınıf öğretmenlerinin görüşleri. Mersin Üniversitesi Eğitim Fakültesi Dergisi, 9(1), 212-224.

Kraatz, M. S. (1998). Learning by association? Interorganizational networks and adaptation to environmental change. Academy of Management Journal, 41(6), 621-643.

Manço, A. A. (2002). Göçmen Türklerin Belçika eğitim sisteminde yeri. C. Ü. Sosyal Bilimler Dergisi, 26(1), 6168.

Meyer, J. W. \& Rowan, B. (1977). Institutionalized organizations. formal structure as myth and ceremony. The American Journal of Sociology, 83(2), 340-363.

Parlar, H. (2012). Bilgi toplumu, değişim ve yeni eğitim paradigması. Yalova Sosyal Bilimler Dergisi, (4), 193209. 
Sakız, H. (2016). Göçmen Çocuklar ve Okul Kültürleri: Bir Bütünleştirme Önerisi. Göç Dergisi, 3(1), 65-81.

Selznick, P. (1996). Institutionalism old and new. Administrative Science Quarterly, 41(2), 270-277.

Selznick, P. (1957). Leadership in administration. New York: Harper \& Row.

Seydi, A. R. (2014). Türkiye'nin Suriyeli sığınmacıların eğitim sorununun çözümüne yönelik izlediği politikalar. SDÜ Fen Edebiyat Fakültesi Sosyal Bilimler Dergisi, (31), 267-305.

Suriyeli Mülteci Çocukların Türkiye Devlet Okullarındaki Durumu Politika ve Uygulama Önerileri. (2015). İstanbul Bilgi Üniversitesi Çocuk Çalışmaları Birimi.

Şen, Ü. (2016). İki dilli Türk çocuklarına Türkçe öğretimi: ilk öğretmenler ve ilk Türkçe dersi öğretim programı. Mersin Üniversitesi Ĕ̈itim Fakültesi Dergisi, 12(3), 1023-1036.

UNICEF (Kasım 2015). Türkiye'deki Suriyeli Çocuklar. http://unicef.org.tr/files/bilgimerkezi/doc/T\%C3\%BCrkiyedeki\%20Suriyeli\%20\%C3\%87ocuklar_Bilgi\%20 Notu\%20Kasim\%202015.pdf adresinden elde edildi.

Yıldırım, A. ve Şimşek, H. (2005). Sosyal bilimlerde nitel araştırma yöntemleri. Ankara: Seçkin Yayınları. 